\title{
Article
}

\section{Study on the Relationship between CSR and Financial Performance}

\author{
Sang Jun Cho ${ }^{1}$, Chune Young Chung ${ }^{1, *}$ and Jason Young ${ }^{2}$ \\ 1 School of Business Administration, College of Business and Economics, Chung-Ang University, \\ 84 Heukseok-ro, Dongjak-gu, Seoul 06974, Korea; cho.sangjuns@gmail.com \\ 2 College of Business, Washington State University, Pullman, WA 99164, USA; jyoung@gmail.com \\ * Correspondence: bizfinance@cau.ac.kr
}

Received: 8 December 2018; Accepted: 4 January 2019; Published: 11 January 2019

\begin{abstract}
This study analyzed whether a systematic relationship exists between corporate social responsibility (CSR) performance and corporate financial performance using 191 sample firms listed on the Korea Exchange. The Korea Economic Justice Institute (KEJI) index of 2015 was used to measure CSR performance; profitability and firm value were used to measure corporate financial performance. Return on assets was used as a proxy for profitability, and Tobin's $Q$ was used as a proxy for firm value. The correlation between these variables and CSR performance was examined through correlation and regression analysis. The results confirm that CSR performance has a partial positive correlation with profitability and firm value. These results are partly consistent with those of previous studies reporting a positive relationship between CSR and Korean firms' financial performance using the KEJI index before 2011. In the relationship between CSR performance and profitability, only social contribution yields a statistically positive correlation. Analysis of the correlation between CSR performance and financial performance indicators revealed a positive relationship between the growth rate of total assets and corporate soundness and social contribution. Both soundness and social contribution showed a positive correlation with Tobin's $Q$, the measure of corporate value.
\end{abstract}

Keywords: KEJI Index; CSR; social contribution; financial performance; profitability; corporate value

\section{Introduction}

\subsection{Background and Purpose of the Study}

Along with the advent and rapid spread of environmental management, the importance of corporate social responsibility (CSR) is gradually increasing. Furthermore, the influence of the social corporate has increased, becoming ever more significant. Society now expects firms to not only produce goods and services but also play a more desirable role in society, rather than being limited to their traditional role. However, companies are not actively coping with this and are being criticized by society [1], indicating that they are not sufficiently trusted by society.

A firm can expect to experience sustainable growth through the trust placed in it by society. Accordingly, if a firm performs trust-based entrepreneurial activities, it can maintain good relationships with various stakeholders, and ultimately expect improvement in economic performance [2].

Furthermore, it has already been verified that companies use CSR as a channel to distinguish themselves from other firms; they have been filling gaps to improve people's quality of life that the government finds difficult to fill [3].

Accordingly, in recent years, CSR activities have been recognized as a natural obligation of firms. As sustainable management has become much more important, firms have begun to recognize CSR internally as an important business strategy. Investors are also recognizing the importance of 
socially responsible investment (SRI), which involves investing in companies with outstanding CSR performance [4].

In the 2000s, CSR is characterized by its implementation at company-wide and strategic levels; namely, at the global level, there have been active efforts and discussions for international standardization of CSR, such as the UN Global Compact. In 2000, the UN enacted the UN Global Compact as an international protocol. This compact established ten principles in four large areas: human rights, labor, environment, and anti-corruption. It classified CSR as an international norm. The International Standardization Organization (ISO) and the Organization for Economic Cooperation and Development (OECD) have also implemented measures to internationally standardize CSR. This work toward international standardization suggests that CSR may become the new trade barrier in the near future, requiring more active and strategic responses from firms [5].

As efforts toward international standardization are increasing and as the environment and ethics of firms are becoming main issues domestically, a new perspective on CSR has become more prominent [6]. One of the major issues related to CSR is how CSR activities affect a company's financial performance. Prior researches on the link between a firm's engagement in CSR and financial performance indicate contradictory results.

However, recent domestic and foreign studies on this topic indicate that CSR activities have a positive (+) effect on financial performance [7]. Many domestic studies on CSR and firm performance use the Korea Economic Justice Institute Index (KEJI index), which is provided by the Economic Justice Institute under the Citizens' Coalition for Economic Justice as a substitute measure for CSR. Previous literature that has used the KEJI Index to study the relationship between CSR and financial performance reports a positive $(+)$ relationship between CSR performance and corporate performance.

The purpose of this study is to examine whether there is a systematic relationship between CSR performance and the corporate financial performance of firms listed on the Korean Exchange. In particular, this study analyzes the relationship using the 2015 KEJI index. CSR literature prior to the end of 2014 used the KEJI index obtained before 2011. After 2012, there has been a substantial change in the way that the KEJI index is calculated: the evaluation item "contribution to economic development" has been excluded. Accordingly, compared with measurements from before 2011, the index's credibility as a proxy for CSR performance has been enhanced.

To conduct the empirical analysis, this study uses the financial data of the top 191 companies selected as good companies by the KEJI at the end of 2015. The KEJI index is used as a proxy variable for CSR activity (the independent variable). The dependent variables include total assets, net profit ratio, total asset growth rate, and Tobin's $Q$. The financial data for control variables (size of the firm, debt ratio) are extracted from the TS 2000 reported by Korea Companies Information. The collected data are briefly examined using descriptive statistics, and the relationships between the variables are analyzed using correlation analysis. Multiple regression models are used to examine the hypotheses, with the empirical analysis conducted via SPSS 23.0.

\subsection{Methodologies and Study Composition}

This study analyzes whether there is a systematic relationship between CSR performance and the financial performance of 191 Korean stock market listed firms studied in the KEJI survey. As described above, in this study, the KEJI of 2015 are used as a proxy to measure CSR performance. The financial performance of the companies is evaluated using profitability and corporate value. Return on assets (ROA) is employed as the proxy for profitability, and Tobin's $Q$ was used as the proxy for corporate value. The impact of CSR on a firm's financial performance is then examined through regression analysis. Additionally, the relationship between CSR performance and financial performance is analyzed using the sales revenue growth rate as a measure of corporate financial performance. Moreover, after 2012, the evaluation item "contribution to economic development", which is more likely to relate to financial performance than CSR performance, has been excluded. Therefore, the studies using this prior KEJI index risk overestimating the relationship. Accordingly, it is necessary to 
reevaluate this relationship using the post-2012 KEJI index. This study uses the KEJI index released at the end of 2015 as a proxy for CSR performance, empirically analyzes the relationship between CSR performance and financial performance, and verifies the results by comparison with previous studies that employed the KEJI index prior to 2011.

Previous literature has generally analyzed the relationship between corporate financial performance and CSR outcomes using single indicators, such as ROA and Tobin's Q. Thus, there has been insufficient research on the relationship between CSR performance and growth rates, an aspect other than profitability that measures financial performance. This study uses not only single indicators, but also the growth rate of sales revenue to examine the relationship with CSR performance. Through this, the relationship between profitability, corporate value, and growth performance is analyzed to examine CSR and corporate financial performance, with the goal of understanding how CSR outcomes increase or decrease ROA, a measure of the overall profitability of the firm.

In addition to the inclusion of several indicators that capture a firm's future growth prospects, we underline the need to consider market discrepancies when studying the possibly heterogeneous impact of CSR on a firm's market valuation. As most CSR literature are established upon the examination of developed markets, especially on the U.S. market, it is difficult to generalize the findings to emerging markets without addressing the contextual differences between the two market types on issues such as corporate governance and corporate environment.

Firms in the emerging economies are most easily discerned by their weak firm-level governance. Hence, it is important to note whether the presumed positive relation between CSR and the firm's market valuation persists even under the weak corporate governance structure. Related to this, both earlier and recent studies, though not unanimously, have reported that, in general, corporate investment in CSR enhances the firm's financial performance and market valuations, and that the market participants scrutinize this investment decision when assessing the firm's market valuations [8-10]. Specifically, firms with better CSR practices are often rewarded with higher firm valuations in Hong Kong and in China [11], and in Romania [12]. In addition, companies with a better sustainability (which can be understood as a broader concept of CSR) reporting score enjoy steeper appreciation of their market values in Singapore [13]. More recently, a study on the Korean market highlights the moderating effect of firm ownership structure on the relationship between CSR and firm value [14]. However, the existing literature on CSR in the Korean market remains relatively elusive due to the distinctive market conditions.

Compared with other emerging economies described thus far, the weak corporate governance issue is especially problematic in the Korean market due to the presence of chaebols, which are large family-oriented conglomerates whose sectors of business operation span across numerous different industries. The owner-managers of chaebols pose immediate and tremendous threat to the establishment of sound corporate governance practices in the Korean market, as they have continued to pursue self-interests, such as succession plans, at the expense of minority shareholders' value erosion. Given the vast number of groups involved in these chaebol firms, the relevant stakeholders, both internal and external, find it difficult to reach a mutual agreement not only among themselves but also with the management on corporate decisions including engagement in CSR activities. Therefore, examining the firms in the Korean market enables us to complement the literature on how CSR practices affect firm value and performance under such weak firm-level governance.

While numerous attempts have been made in understanding the effect of CSR on corporate performance and on firm value in Korea, the available empirical evidence remains equivocal. Furthermore, many fail to note how the corporate trend in terms of CSR has undergone significant changes since the 1997 Asian financial crisis. The market failure in 1997, which was primarily prompted by less-restrained corporate borrowing, led the Korean government to initiate a series of stringent financial regulations that pressurized Korean firms to adopt more responsible business practices including investment in CSR-related projects [15]. Ever since, stakeholders whose values were utterly destroyed by the crisis have been progressively demanding that the firms protect their rights and meet 
social obligations [16-18]. In response to these growing demands, Korean firms have been increasing their investment in CSR to restore their damaged reputation [19-21]. This corporate trend towards CSR-adoption continues to exist and many large profitable firms in the Korean market plan to increase their investment in CSR activities on a yearly basis, with some even declaring that they will spend a proportion of their net profit margin in financing CSR-related projects such as social contribution, charity, and CEO donation programs. As CSR has become an irreplaceable part of business culture in Korea over the last two decades, it is critical to investigate the impact of a firm's CSR engagement on its financial performance and value.

This study contributes to the literature in the following ways. First, we provide additional empirical evidence of the positive association between corporate social responsibility (CSR) and firm performance by utilizing accounting- and market-based measures. Second, we perform an exhaustive investigation of more recent data, not yet extensively covered by prior researches, and observe CSR from various perspectives. Lastly, our study is among the few that examine whether corporate investment in CSR activities uniformly improves corporate performance and market valuations. Thus, our in-depth analysis of the Korean firms provides practical implications to policy makers, market participants, and academic researchers in the emerging market.

\section{Theoretical Background}

\subsection{Corporate Social Responsibility}

\subsubsection{Concept of CSR}

CSR refers to a firm fulfilling its legal, economic, ethical, and philanthropic responsibilities to society [22]. Generally, CSR is interpreted as a firm's social contribution. However, CSR and social contribution must be clearly differentiated: social responsibility refers broadly to a firm's legal, economic, ethical, and philanthropic responsibilities, while a firm's social contribution refers to only one aspect of CSR [23]. Therefore, it is not accurate to simplify the concept of CSR into social responsibility; thus, CSR will be redefined using the concepts in various CSR studies.

Bowen [24] first developed an academic definition of social responsibility as a concept of CSR; in his book Social Responsibility of Businessmen, he defines social responsibility as the pursuit of the right policy in terms of social goals or values, describing it as the duty of businesspeople to follow such decisions and actions [25]. Since then, many definitions have been suggested, with no single unique definition of CSR. Because discussions about CSR are broad and comprehensive, it can be defined from many different approaches and perspectives [26].

Examining the domestic literature, Shin [1] defines social responsibility as a normative framework of corporate behavior that should meet the expectations and needs of the public and of the company's stakeholders by resolving various social and economic problems via corporate actions. Furthermore, examining the definition of CSR by major global institutions, the OECD defines CSR as the social responsibility of a firm to continuously develop the mutual growth relationship between itself and society. As a result, there are several perspectives and definitions of social responsibility, but the most general definition of CSR used in studies is that suggested by the European Commission in 2001: "firms voluntarily interact with their stakeholders and integrate social and environmental concerns to corporate management" [27]. The most recent definition of CSR is provided in ISO26000 (released: November 2010) by the International Organization for Standardization (ISO): "firms' decision making in accordance with transparent and ethical behavior and the responsibility of the firms on the impact of the organization's decisions and activities on society and the environment" [28]. ISO 26000 is the first international standard concerning CSR, and applies to all organizations, including corporations [29]. 


\subsubsection{Necessity and Importance of CSR}

The issue of the social responsibility of Korean companies has been actively discussed since the beginning of the 21st century. While firms have been skeptical in the past, CSR has become a firm behavior that addresses ethical and other problems, and should be considered as a part of business activities. Furthermore, because CSR activities can eventually result in the financial success of the firm, more and more firms are strategically using CSR as a means of marketing [30]. So far, CSR activities have been conducted either benevolently or mandatorily as the social return of wealth accumulated by entrepreneurs and firms, but now, the focus on CSR should shift toward a strategic dimension. By contrast, in the past, firms have taken rather defensive or passive positions, and CSR was more concerned with the personal preferences of the CEO. It was regarded as a secondary activity centered on related personnel. Social contributions had been limited to physical support, and direct interaction with the recipient was also limited [31]. Examining the global trend, the Washington Post reports nearly 100,000 pages of firm websites related to CSR. Amazon has 600 books about CSR, more than 200 mutual funds are making SRIs, and more than 2000 companies prepare annual CSR reports. Indeed, the United Nations is the best sponsor in this area. Business schools have also developed courses concerning CSR, with contributions from many newsletters and consultants [32].

Considering this situation, as consumers' concerns and demands for CSR increase, companies are under pressure to carry out activities that contribute to society and have realized that these charitable and donation activities are investments that can enhance the value of firm assets. Indeed, through various CSR activities, whether firms are deemed socially responsive can be an important criterion for consumers' purchase decisions, and beliefs about whether the firm is ethical, moral, environmentally friendly, or demand-responsive [33]. On the contrary, it is widely recognized that consumers' perception that a company seeks only commercial profits can be a weakness. In this sense, it is said that CSR activities are "marketing techniques that enable companies to pursue both economic and social goals simultaneously" [34].

Recently, studies such as the one by Lee [35] suggest that as CSR becomes widespread, social responsibility is important for firms for several reasons. First, based on the win-win idea that both economic values and social values are important, strategic corporate social activities eventually benefit firms. Striving to ensure the health and safety of citizens and developing corporate activities that meet the needs of each stakeholder, like caring for social and environmental issues, human rights, and information disclosure, are ultimately the pursuit of the common interests of the firm and its stakeholders.

Second, when a firm fulfills its social responsibilities, it can build closer relationships with each of its stakeholders.

Third, to gain the satisfaction of each stakeholder, it is necessary to have a long-term perspective rather than a short-term perspective. Firms that value social responsibility can seek long-term profits even if they have to sacrifice short-term profits.

Fourth, when evaluating a firm from a wide perspective, if it fulfills its social responsibilities, it receives good evaluations and a good reputation from society and consumers. Consumers want to buy goods and services from reputable companies, and outstanding talent is attracted to principled firms. Furthermore, many firms have strong tendencies to do business with other firms that share values similar to theirs.

Fifth, as a firm fulfills its social responsibility, it can be recognized as a firm with outstanding corporate management capabilities (especially by investors) and with sufficient financial capacity.

\subsubsection{CSR and Firm Value}

As firms operate within the social boundaries, they have multiple obligations to fulfill, not only limited to those outlined by shareholders, but also to those necessitated by stakeholders. The roots of corporate social responsibility (CSR) can be traced back to the idea of corporate volunteering and the emergence of the social welfare concept in the late nineteenth century [36,37]. However, ever since its 
first inception, the meaning of CSR has undergone substantial developments and become increasingly sophisticated. Given this context, corporate responsibility can be classified into four distinct categories in order of decreasing importance: economic, legal, ethical, and voluntary duties [38,39].

First, a firm is expected to meet its economic responsibility. Indeed, the primary purpose of an enterprise is to generate and maintain sustainable corporate profits by the means of creating and providing the necessary products and services to society. The second most essential duty required of a firm is legal responsibility. As businesses operate within legal boundaries and are protected by national borders, they must strictly adhere to regulations set forth by their respective governments and be transparent to the public and to the relevant stakeholders. On the other hand, a firm's ethical responsibility, such as social support events, can be regarded as a set of ideals that if followed produce a social surplus, but are not mandatory. Lastly, a firm is expected to carry out its voluntary responsibility which entails participating in philanthropic activities such as giving monetary aids to the socially disadvantaged. Related to this classification of corporate responsibility, Carroll [8] addresses that these four main categories of corporate responsibility are not equally important and advises that they should be performed stepwise in the order of importance. For example, firms should consider meeting economic responsibility first and foremost and subsequently, plan fulfilling legal responsibility.

Naturally, it is hard to contain such a broad concept as corporate social responsibility into single terminology. Indeed, CSR can be defined in several different ways, with even large organizations failing to reach an agreement on its concept and precise meaning. For example, the Commission of the European Communities and the International Organization of Employers approach CSR from a macroscopic perspective, defining it as a voluntary concept whereby firms implement various socio-economic and environmental concerns in their corporate activities and in their interaction with stakeholders. The aforementioned voluntary concept of CSR resonates with the definition provided by the International Labor Organization, which views CSR as firms' commitment to sustainability that is beyond the legal requirements. The World Business Council for Sustainable Development adds a much broader perspective of CSR, stating that it must be interpreted as corporations' dedication to sustainable development and better quality of life by cooperating with the whole society, whereas the United Nations Conference on Trade and Development interprets CSR more narrowly, defining it as firms' means to comply with their social obligations.

Similarly, the existing literature offers many different definitions for CSR and thus, the concept of CSR cannot be defined by single terminology [40,41]. Due to the lack of precise definition, the concept of CSR is often used interchangeably with that of social contribution, sometimes yielding erroneous interpretations. Hence, it is indispensable to provide an unambiguous definition of CSR, however narrow or broad, before conducting research. For instance, a large body of literature defines the concept of CSR as a duty to society and to pertinent stakeholders [42,43], an ethical responsibility and management process [44], and interprets CSR as attempts made by corporations to improve the social environment on a voluntary basis [45]. However, a portion of the existing literature, most notably [46], narrows down the concept of CSR and argues that CSR can be understood as corporate profit maximization under legal and ethical obligations and providing maximal value to the stakeholders. Some researches, including [47], define CSR in a much broader context and assert that socially responsible business practice involves enlarging social benefits not limited to corporate profit nor that required by law.

However, relatively few numbers of studies examine the link between firms' financial CSR activities and firm value. Prior studies document that many charitable donations are driven by the goal of corporate profit maximization and by managerial self-interest $[48,49]$. By examining the association between CSR and the firm's capital structure, the study suggests that there is the possibility of firm value deterioration due to corporate investment in CSR activities [50]. From the agency problem perspective, they add that a manager is innately predisposed to allocate corporate resources beyond the optimal level on CSR-related projects in order to obtain private benefits, such as personal reputation, possibly resulting in a drop in firm value, due to the heightened agency conflict between stockholders 
and managers [51]. Meanwhile, another study investigates CSR from wide spectra and report that the firm's choice of CSR depends on a host of firm-specific characteristics such as accounting qualities (profitability, level of R\&D expenditure and diversification, size, and debt ratio) and governance structure (independence of the board of directors and institutional investors' ownership size) [52-54].

Despite the increasing importance of CSR, a little attention is paid to examining the relationship between a firm's CSR activities and its market valuation. Furthermore, the available empirical evidence remains relatively inconclusive. Some studies establish a negative association between the two, based on the findings that firms with high levels of corporate expenditure on social and environmental issues relinquish their strategic advantages to competitors and thus become more susceptible to financial losses [55,56] and financial distress [57]. Based on an event study, literature corroborate a negative relation between a firm's choice of CSR and abnormal returns [58]. Yet, a large body of literature reports that a firm's choice of CSR increases firm value, with 33 out of 52 studies reporting similar finds, five reporting a negative relationship between the two, and 14 reporting statistically insignificant relation [59]. More specifically, companies that adopt more socially responsible business practices enjoy better corporate outcomes [60], better financing capabilities such as profits, leverage ratio, and debt-repayment capability [61], lower transaction costs and reduced probability of conflicts with stakeholders [62], better financial accomplishments [63,64], higher short-term abnormal returns [65], and an improved brand image that leads to increased strategic competitiveness and firm value [66-68].

Likewise, researches on the Korean market generally report a positive link between CSR and firm value. Based on the comprehensive analysis of firms' environmental performance, which is one of the subdimensions of CSR, Park et al. [69] conclude that firms that are more dedicated to protecting the environment produce better financial outcomes. Similarly, when corporate spending on CSR is decomposed into expenses on environmental protection and into expenses on donation, which is also considered as one of the subdimensions of CSR, both [70] and [71] report that higher donation expenses improve the firm's financial performance and its market valuation. Researchers also show that CSR has a positive influence on the firm's market value (or Tobin's Q) [72], with some claiming that the initial cost of investment in CSR will eventually be outweighed by the savings from reduced long-term costs and by the profits from increased revenues, due to enhanced corporate reputation in the long-run [73]. As such, the conventional wisdom on CSR and firm value seems to establish a positive link between the two [74,75]. Hence, our research is conducted based on the presumption that a firm's CSR engagement increases firm value.

\section{Previous Literature}

\subsection{Examination of Previous Literature}

Studies on the effects of CSR activities on financial performance can be divided into those that argue that the correlation is positive and those that argue the opposite. The former research stream concludes that additional revenue earned by firms from CSR exceeds the costs incurred. However, the latter argues that the costs incurred to conduct CSR activities exceed the profits from them, thus resulting in a decrease in profits [76].

First, the studies that argue a negative correlation between CSR and firm financial performance emphasize economic responsibility as the foremost responsibility of firms. Firms must focus on achieving the basic and ultimate goals of maximizing shareholder profits, and fulfilling legal responsibilities in compliance with laws and regulations through that process is sufficient. Accordingly, CSR activities, ethical responsibilities, and donations reduce the economic profits of shareholders. CSR activities that deviate from economic and legal responsibilities can even negatively affect the maximization of profits and shareholder values, ultimately affecting the profits of stakeholders [77].

McWilliams and Siegel [20] argue that CSR activities increase costs beyond the company's original management activities, an infringement of shareholder interests. They argue that being loyal to the original purpose of maximizing shareholder profits is in itself the fulfillment of social 
responsibility, given that the responsibility of firms is to create jobs and develop the economy. Davis (1973) [35] analyzed the relationship between CSR and the financial performance of British firms. Financial performance was measured using the price earnings ratio, CSR performance was measured individually in three separate categories of environment, employment, and community service, and comprehensive performance indicators were employed; the study identified a negative correlation between CSR performance and the price earnings ratio, which was particularly large in the environmental sector. Barnea and Rubin (2010) [36] analyzed the relationship between CSR and corporate value. Their argument was based on agency theory. They argued that when managers spend excessively on CSR activities to pursue private utilities or manage their own careers, it increases agency costs, thus leading to a reduction in firm value. Among Korean studies on CSR, some report a negative influence of CSR on the firm financial performance and values. Shin et al. (2011) [37] analyze the relationship between donation expenditure and corporate value, revealing that initially firm donation spending and firm value are positively $(+)$ related. However, after the appropriate level is reached, the correlation changes to negative $(-)$, which they interpret based on agency theory. As managers spend excessively on CSR activities for private interests, agency costs are increased, thus infringing on shareholder interests and eventually diminishing corporate value.

In previous Korean literature, studies reporting a negative correlation between CSR performance and financial performance are rare. Kook and Kang (2011) [38] conclude that there is a positive correlation between CSR and financial performance when corporate governance is outstanding, but no positive correlation is found when corporate governance is relatively inferior.

On the other hand, some studies deny any correlation between CSR and financial performance [78,79]. McWilliams and Siegel [20] report that there is no significant correlation between CSR and corporate performance, and that other research shows positive or negative correlations simply because of problems with the study design.

Nelling and Webb (2009) [39] report that there is no statistically significant relationship between CSR and corporate financial performance when excluding time-series effects. They argue that the positive correlation shown in previous literature will weaken if the research models are designed in more detail. Thus, they argue that CSR cannot increase corporate financial performance.

By contrast, many studies that examine the influence of CSR on firms' financial performance report a positive correlation [80-82].

Those that report a positive correlation are based on stakeholder theories and emphasize the social role of firms. As the size and influence of firms grow, so do the social responsibilities that they should fulfill.

Freeman (1984) [30] and other proponents of stakeholder theories state that firms are not merely profit-seeking organizations, but must satisfy the needs of firm stakeholders, and that firms must strive to receive social support as corporate citizens [83]. In this sense, they believe that CSR activities can alleviate conflicts of interest between firms and stakeholders, and ultimately increase financial performance and corporate value [84,85].

Since many problems in modern society are related to corporate activities, firms are responsible for solving these issues by themselves, and if they continually ignore societal expectations, social problems can be intensified, leading to an increase in their operating costs. Furthermore, firms primarily bear economic responsibility, but they also must bear legal, ethical, and philanthropic responsibility as members of society [86].

Through a questionnaire survey of corporate stakeholders and quantitative analysis using the KLD index, Ruf et al. (2001) [47] report that the higher the level of satisfaction firms provide to stakeholders, the higher their financial performance.

Garcia-Castro et al. (2011) [48] use 658 firm year results and the KLD index to examine the relationship between firms' CSR performance, and financial performance measured by ROA, return on equity (ROE), the price earnings ratio (MVA), and Tobin's $Q$. 
Early Korean research on the link between a firm's CSR adoption and corporate financial outcomes only focuses on some CSR activities. For example, Jung and Kim (2008) [49] examine the correlation of the production costs of environmental facility investments and profitability; their empirical analysis reveals a negative correlation between environmental investment and the total cost incurred. Wei (2006) [50] and Choi et al. (2009) [51] study the correlation between donation expenditure and corporate values.

After analyzing listed firms in 2014, Jung and Kim (2008) [49] report that an increase in investments in environmental facilities lead to a curtailment in costs. However, they find no evidence of an increase in sales revenue due to increased firm attractiveness after investing in environmental facilities.

Choi et al. (2009) [51] empirically analyze the relationship between CSR activities and financial performance using donation expenditure as the proxy measurement for CSR, concluding that CSR is an intangible asset investment, which can be used to enhance a firm's reputation. However, it is also privileged consumption made by discretionary manager decisions to enhance private utilities and there are risks of overinvestment, which could have negative effects. Accordingly, this study predicts that firm value and CSR will have a reverse U-shaped relationship. For empirical analysis, the study uses pooled ordinary least squares (OLS) and conducts a fixed effects panel analysis, and a random effects panel analysis for market listed companies from 1999 to 2005. Indeed, the results confirm a reverse U-shaped non-linear relationship between CSR (measured by donation expenditure) and firm value.

Much of the Korean literature has used the quantitative evaluation KEJI Index by the Citizens' Coalition for Economic Justice (CCEJ) as a proxy measurement for CSR. Jang and Choi (2010) [12] analyze the relationship between CSR performance and profitability (ROA), corporate value (Tobin's Q), and capital cost using the KEJI index as the measurement of CSR performance for 130 companies from 1998-2005. The results show that CSR performance has a positive relationship with accounting profit returns (ROA) and firm value (Tobin's Q). However, the relationship between CSR performance and capital cost is identified as positive, contradictory to the study hypothesis of a negative relationship.

$\mathrm{Na}$ and Hong (2011) [33] used the KEJI index to empirically analyze the correlation between continuous individual CSR activities and corporate value (Tobin's Q). Furthermore, they investigate how the correlation differs according to firm size. This study analyzes 74 firms with known KEJI indexes over five consecutive years from 2004 to 2008, revealing a positive correlation between corporate value and employee satisfaction and contribution to the economy. However, corporate value and environmental protection activities are found to have a negative correlation. Furthermore, environmental protection activities, employee satisfaction, and contribution to economic development-the factors significant to corporate values-are found to have a different impact on corporate values depending on firm size. That is, these factors are shown to exert stronger effects on large firms than on small firms.

Kim and We (2011) [52] use 186 KEJI indexes from 2003 to 2009 to analyze the relationship between CSR performance and ROA and the price earnings ratio. According to the analysis, the sum of the KEJI indexes has a positive correlation with ROA and the price earnings ratio. Furthermore, by integrating seven evaluation items of the KEJI index, the study reclassifies them into contribution to society service, contribution to economic development, and integrated index to analyze the correlation with financial performance. According to the results for each index, contribution to society service has no influence on ROA or the price earnings ratio, and the integrated index has a positive correlation only with ROA, while contribution to economic development has a positive correlation with both ROA and the price earnings ratio.

Kim et al. (2015) [53] examine KEJI indexes for 6 years (2005-2010) to verify the correlation between CSR performance and accounting performance (ROA). The results show that the overall CSR performance is positively correlated with ROA, but there is no U-shaped relationship. Detailed analysis of the relationship between CSR performance and accounting performance (ROA), soundness of the firm, employee satisfaction, and contribution to economic development reveal a positive U-shaped 
relationship, but customer protection satisfaction has a reverse U-shaped correlation. However, in terms of ROA, the U-shaped correlation is found only for the correlation between soundness and accounting performance.

Thus, although the conclusions of the research on the correlation between CSR performance and financial performance are mixed, many domestic and foreign studies today report that CSR activities positively affect financial performance [87]. Since it is extremely difficult to measure the level of CSR comprehensively and subjectively, CSR studies have been limited to separate actions such as investment in environmental facilities [88] or charitable donations [89,90]. However, many domestic studies have used the KEJI index as a proxy measurement for CSR activities to study the systematic relationship with financial performance. Most studies using the KEJI index report that CSR performance and financial performance are positively related [91-95].

\subsection{Limitations of Previous Literature and What Makes This Study Different}

Previous literature uses the KEJI index prior to 2011, which includes the evaluation item contribution to economic development. As explained above, this KEJI index was measured by the seven criteria of soundness, fairness, contribution to social service, consumer protection satisfaction, environmental protection satisfaction, employee satisfaction, and contribution to economic development. Among the evaluation items, contribution to economic development accounted for 10 out of 100 points.

The evaluation item contribution to economic development comprised "R\&D spending", "profitability", "growth in dividend payout ratio", and "labor productivity growth", items more relevant to financial performance than CSR. Hence, to use the KEJI index as a pure substitute measurement for CSR, it is necessary to exclude the evaluation item contribution to economic development, reducing the seven criteria to six. Since 2012, the KEJI index has excluded contribution to economic development, which is a measure of financial performance. Accordingly, the post-2012 KEJI index has enhanced representativeness as a measurement of CSR. Thus, the likelihood of overvaluation between CSR and financial performance is also reduced.

Moreover, since all of these previous studies analyze the relationship between CSR performance and financial performance using data from 2011, there is a high risk that the relationship is overestimated. Therefore, it is necessary to use the post-2012 KEJI index, which excludes the item contribution to economic development (which strengthens its reliability as a measurement of CSR performance) to reanalyze the correlation and reexamine the results of existing studies. This study uses the KEJI index from the end of 2015, which excludes contribution to economic development, to empirically analyze the correlation between Korean firms' CSR and financial performance, and to compare and confirm the results of previous literature. The KEJI index is calculated for companies listed on the Korea Exchange, but excludes companies with deficits, impaired capital, and times interest earned ratios below 1.0.

Finally, most previous studies analyze financial performance of firms using single indicators like ROA and Tobin's Q to measure financial performance and its relationship to CSR performance. Thus, the relationship between growth performance (another important indicator of financial performance other than those related to return on total assets or capital, such as ROA or ROE) and CSR performance has not yet been analyzed. In this study, the sales revenue growth rate and Tobin's $\mathrm{Q}$ are used as proxy variables for corporate financial performance to analyze the correlation with CSR performance. Through these, this study analyzes the correlation between CSR performance and financial performance measured by profitability, corporate value, and growth potential, and aims to enhance our understanding of how CSR performance affects a decrease or increase in ROA, the variable for overall profitability. 


\section{Establishment of Hypotheses and Research Design}

\subsection{Research Hypotheses}

This study examines the relationship between CSR and corporate financial performance using $191 \mathrm{KEJI}$ indexes calculated at the end of 2015 and verifies the results of previous literature that used the KEJI index before 2011. To analyze how CSR performance affects corporate financial performance, the following hypotheses are established for analysis:

The results of studies on the correlation between CSR and financial performance are mixed in that some argue that it is positive, while others argue that it is either negative or even unrelated. However, recent Korean studies using the KEJI index report a consistent positive relationship. This study first reviews the profitability growth potential and corporate values among various indexes for corporate performance and establishes research hypotheses that assume positive directionality between CSR performance and these three variables. The related studies rely on either accounting-based measures or market-based measures to measure the financial performance of CSR activities. Accounting-based indicators reflect past, short-term financial performance, while market-based indicators reflect future, long-term aspects [96-101]. We consider both accounting-based and market-based measures in order to incorporate both perspectives of the financial performance measures.

Jang and Choi (2010) [12] report a positive correlation between CSR performance and ROA. Chon and Kim (2011) [55] report that the firms that continuously conduct outstanding CSR experience a statistically significant positive influence on business performance.

According to the previous literature, there is a positive correlation between CSR activities and indexes of profitability [102,103]. To confirm this, Hypothesis 1 is established as follows:

Hypothesis 1. CSR will exert a statistically significant influence on firm profitability.

As companies carry out their CSR activities, they can improve their image. Furthermore, this can provide a competitive edge to a firm in a competitive market, thus affecting its growth. Kim (2009) [95] reports that the sub-items of CSR exert a statistically significant influence on firms' partial growth indicators; this is tested through Hypothesis 2:

Hypothesis 2. CSR will exert a statistically significant influence on firm growth potential.

Companies improve their financial performance by conducting CSR activities. Lee (2007) [67] reports that there is a positive correlation between CSR performance and Tobin's $Q$, an indicator of firm value. Yeo et al. (2015) [60] analyze listed Chinese firms and conclude that CSR affects Tobin's Q. Therefore, Hypothesis 3 is established based on the results of previous literature:

Hypothesis 3. CSR will exert a statistically significant influence on firm value.

\subsection{Research Design}

\subsubsection{Research Model}

Hypothesis 1 assumes a positive correlation between CSR performance and profitability.

A regression equation is used to confirm the influence of CSR on financial performance. Financial performance is primarily studied through profitability, growth potential, and firm value. This study clarifies the effects of CSR activities on firm profitability, growth potential, and value.

$$
\mathrm{ROA}=\mathrm{a} 0+\mathrm{a} 1 \mathrm{LNCSR}+\mathrm{a} 2 \mathrm{LNSIZE}+\mathrm{a} 3 \mathrm{LEV}+\mathrm{e}
$$

Here,

ROA: a proxy variable for firm financial performance (return on assets) 
LNCSR: the natural log value of the KEJI index

LNSIZE: the natural log value of the total assets (term-end total assets, a measurement of firm size) LEV: the debt ratio (total debt/total equity)

e: residual

ROA (accounting return), which is the most widely used proxy variable for profitability (dependent variable), is used here. The ROA is obtained by dividing net profit for the term by total assets.

$$
\text { GROWTH }=\mathrm{a} 0+\mathrm{a} 1 \mathrm{LNCSR}+\mathrm{a} 2 \mathrm{LNSIZE}+\mathrm{a} 3 \mathrm{LEV}+\mathrm{e}
$$

Here,

GROWTH: the growth rate of sales revenue (variation in sales revenue/sales revenue of the previous term)

LNCSR: the natural log value of the KEJI index

LNSIZE: the natural log value of the total assets (term-end total assets, a measurement of firm size) LEV: the debt ratio (total debt/total equity)

e: residual

$$
\mathrm{TQ}=\mathrm{a} 0+\mathrm{a} 1 \mathrm{LNCSR}+\mathrm{a} 2 \mathrm{LNSIZE}+\mathrm{a} 3 \mathrm{LEV}+\mathrm{e}
$$

Here,

TQ: Tobin's Q

LNCSR: the natural log value of the KEJI index

LNSIZE: the natural log value of the total assets

LEV: the debt ratio

e: residual

Tobin's $Q$, the representative indicator of market value, is used as a proxy variable for firm value (dependent variable). ROA only reflects the firm's past performance, and because of accounting and managerial manipulation, it is difficult to compare among firms. By contrast, Tobin's $Q$ reflects the value of the firm to shareholders and is easy to compare among companies as there is no possibility for accounting manipulation, such as depreciation. Moreover, it is advantageous in that it reflects future profits through the evaluations of investors [104-110].

The calculation of Tobin's $Q$ follows the method suggested by Chung and Pruitt (1994) [61]:

Tobin's $\mathrm{Q}=$ (market value of common shares outstanding + market value of preferred shares outstanding + book value of debt)/book value of assets

\subsubsection{Sample Selection}

The study samples are the KEJI index measured by the Economic Justice Institute and 191 indexes surveyed at the end of 2015. The KEJI indexes calculated in 2015 include firms with available financial performance variables and other variables in TS2000 of the Korea Companies Information.

The KEJI index is calculated for companies listed on the Korea Exchange, but excludes firms with deficits, impaired capital, and times interest earned ratio below 1.0, according to the principles for selecting firms to include in KEJI evaluation. For a consistent evaluation of the KEJI evaluation items environmental protection satisfaction is excluded, and firms from the finance and insurance industry are removed, considering that this industry presents large differences in its evaluation results compared with other industries. 


\subsection{Definition of the Variables}

\subsubsection{Independent Variables}

As previously described, Korean studies on CSR primarily use the KEJI index as a measurement of CSR performance. The KEJI index prior to 2011 was measured by seven criteria: soundness, fairness, contribution to social service, consumer protection satisfaction, environmental protection satisfaction, employee satisfaction, and contribution to economic development. In 2012, the evaluation item contribution to economic development was excluded, reducing the seven criteria to six. As with RED expenditure, profitability, growth potential, payout ratio, and labor productivity growth rate, contribution to economic development is more concerned with financial performance than CSR performance. Accordingly, it is necessary to exclude the evaluation item contribution to economic development from the criteria [111] in order to use the KEJI Index as a pure substitute measurement for CSR.

From the end of 2015 to date, previous literature on CSR has used the KEJI index data prior to 2011, and not post-2012 data, which exclude the evaluation item contribution to economic development.

The evaluation items and evaluation weights for each item are introduced in Table 1.

Table 1. Six evaluation items of the Korea Economic Justice Institute (KEJI) index and their contents.

\begin{tabular}{lll}
\hline Item & Weight (100) & Contents \\
\hline Soundness & 25 & $\begin{array}{l}\text { Composition of shareholders, soundness of investment } \\
\text { expenditures, capital procurement, incidences of tax evasion, } \\
\text { etc. }\end{array}$ \\
\hline Fairness & 20 & $\begin{array}{l}\text { Fair trade, transparency in accounting, activities of } \\
\text { nonexecutive directors, etc. }\end{array}$ \\
\hline Contribution to Societal Welfare & 15 & $\begin{array}{l}\text { Protection and employment of the underprivileged, donations, } \\
\text { social welfare support, etc. }\end{array}$ \\
\hline $\begin{array}{l}\text { Satisfaction on Customer } \\
\text { Protection }\end{array}$ & 15 & Consumer rights protection, quality, advertisement, etc. \\
\hline $\begin{array}{l}\text { Satisfaction on Environmental } \\
\text { Protection }\end{array}$ & 10 & $\begin{array}{l}\text { Environmental accounting disclosure, energy efficiency, } \\
\text { environmental investment, pollution performance. }\end{array}$ \\
\hline Satisfaction of Employees & 15 & $\begin{array}{l}\text { Human resources investment, labor relations, employment } \\
\text { gender equality, shareholding system for employees. }\end{array}$ \\
\hline
\end{tabular}

Source: Sourcebook of Economic Justice Firm Prize [62], p. 35.

\subsubsection{Dependent Variables}

Previous literature uses diverse variables as measures for corporate financial performance and firm value. This study uses ROA, total growth rate of assets, and Tobin's $Q$.

(1) Indicators of Profitability

The profitability ratio is a representative indicator of financial performance and refers to the firm's ability to generate profits-monetary performance. The profitability ratio is an indicator that measures the overall efficiency of a firm and represents the comprehensive performance of firm decision-making and policies. For companies to grow sustainably, they need continuous provision of investment funds, and of course, profitability above a certain level. From this perspective, this is the ratio that investors, creditors, and executives are all concerned with [112]. ROA, the leading indicator of profitability, has been used most frequently as a proxy variable for financial performance in previous literature that studies the correlation between CSR and financial performance.

$$
\text { ROA = Current Income } / \text { Total Assets }
$$

ROA is the ratio of current income to total assets. ROA measures how efficiently total assets are used to generate management performance. 


\section{(2) Indicators of Growth}

Growth ratios measure how the scale and performance of a firm have increased over a particular period. Prior studies use growth indicators to measure the financial performance of CSR activities (see, for example, [113]) because they measure the growth rate of each item in the financial statements over time. Typical growth rates include sale revenue growth, total assets growth, and earnings growth per share. This study uses the growth rate of sales revenue.

Growth Rate in Sales Revenue $=$ Increase in the Total Assets this term $/$ Total Assets at the end of the Previous Term

Increase in sales revenue is an indicator that measures the overall growth of a firm. It measures how the total assets managed by the firm have increased over the year.

(3) Indicators of Firm Value

Tobin's $Q$ represents the market value of a firm's total assets capital divided by the replacement cost of its assets. American economist James Tobin first suggested this concept. This indicator is used to explain the trend in capital investment or to evaluate firm value.

If the calculated $Q$ ratio is greater than 1, it means that the total amount of market value of the firm is greater than its real replacement cost, leading to an increase in investment. By contrast, if the $Q$ ratio is less than 1 , it leads to a decrease in investment.

Tobin's $Q=$ (market value of common shares outstanding + market value of preferred shares outstanding + book value of debt)/book value of assets

\subsubsection{Control Variables}

In addition, because this study focuses on investigating the influence of CSR on firm value and performance, we must control for other factors that may affect firm value which may be associated with CSR. Hence, we construct firms' characteristic variables in order to address any problematic issues. Specifically, we use firm size (SIZE), leverage ( $L E V)$, research and development expenses $(R \mathcal{E} D)$, book-to-market ratio $(B M)$, cash flows from operating activities $(C F)$, and the standard deviation of daily stock returns $(V O L)$. For a firm $i$ in year $t, S I Z E$ is the natural logarithm of sales; $L E V$ is the total debts divided by market value of equity (common share outstanding times stock price); $R \mathcal{E} D$ is the $R \& D$ expenditure divided by sales; $B M$ is the total equity divided by the market value of equity; and $C F$ and VOL are cash flows from operational activities divided by total assets and the standard deviation of daily stock returns, respectively. Previous studies document that CSR is related to a firm's performance, liquidity, risk, and size. A firm's size predicts CSR, as a larger firm is more likely to be subjected to external pressures [114]. Financial slack also affects CSR activities, and that leverage and asset tangibility measured by R\&D expenses capture the credit constraints of a firm [115]. R\&D expenses are important factors affecting CSR adoption [116]. Book-to-market ratio is also considered because it is related to CSR [117]. A firm's operational cash flow explains CSR activities [118]. In addition, Return volatility, as a measure of a stock's liquidity, influences CSR [119].

\section{Empirical Analysis}

While simultaneously improving corporate financial performance and sustainability, CSR may also benefit the wealth and rights of stakeholders. It has, therefore, been emphasized by both academic researchers and practitioners; however, few studies have utilized the KEJI index in the Korean market. In their recent study, associate corporate environmental responsibility, a subset of CSR, with stakeholders' rights based on the KEJI index [120]. Through the comprehensive examination of the data set, we aim to find empirical evidence for the effect of direct and indirect corporate social responsibility efforts, as measured by the KEJI Index, on firm financial performance. To verify the 
research hypotheses, the correlations among variables are first analyzed and multiple regression analysis is conducted.

\subsection{Descriptive Statistics}

We report the descriptive statistics of CSR scores and main variables employed in this study in Tables 2 and 3. Table 2 shows the CSR variables, namely, the detailed evaluation items of the KEJI index, the number of observations in the quantitative evaluation, the minimum value, maximum value, mean, and standard deviation. The samples used in the descriptive statistics use the KEJI index measured by the Korean Economic Justice Institute, and 200 indexes investigated at the end of 2015 are used. The average values of the detailed items include soundness at 17.5, social contribution at 16 , fairness at 6.6, protection of consumer rights at 9.6, environmental protection satisfaction at 5.31, and customer satisfaction at 9.64 .

Table 2. Value of descriptive statistics on CSR.

\begin{tabular}{cccccc}
\hline Name of Variable & N & Min & Max & Average & Standard Deviation \\
\hline KEJI-So & 191 & 13.43 & 21 & 17.5231 & 1.4289 \\
KEJI-Fair & 191 & 11.75 & 17.15 & 15.9649 & 0.9701 \\
KEJI-CSS & 191 & 4 & 8.92 & 6.6126 & 1.2232 \\
KEJI-CPS & 191 & 6.65 & 10.6 & 9.6018 & 0.7357 \\
KEJI-EP & 191 & 4.1 & 7.45 & 5.3086 & 0.7593 \\
KEJI-ES & 191 & 7.04 & 11.22 & 9.6365 & 0.8392 \\
\hline
\end{tabular}

Table 3. Value of descriptive statistics on financial performance.

\begin{tabular}{cccccc}
\hline Name of Variable & $\mathbf{N}$ & Min & Max & Average & Standard Deviation \\
\hline ROA & 191 & -12.06 & 26.93 & 4.8212 & 4.99291 \\
GROWTH & 191 & -38.75 & 64.69 & 0.9358 & 13.37669 \\
TQ & 191 & 0.5184 & 12.1597 & 1.5088 & 1.3917 \\
SIZE & 191 & 10.5597 & 18.9452 & 12.9841 & 1.4363 \\
LEV & 191 & 5.88 & 379.64 & 72.653 & 61.6523 \\
R\&D & 191 & 0.0000 & 0.3312 & 0.0091 & 0.0341 \\
BM & 191 & 0.0563 & 9.3121 & 1.8921 & 0.9822 \\
CF & 191 & -0.3811 & 0.6712 & 0.0521 & 0.0654 \\
VOL & 191 & 0.0861 & 1.7123 & 0.4213 & 0.2312 \\
\hline
\end{tabular}

Table 3 shows the correlation between the index for profitability (ROA/the index for financial performance), index for growth potential (total asset growth rate), the firm value index (Tobin's $Q$ ), and the control variables (firm size and debt ratio). The table also shows the minimum value, maximum value, average and standard deviation. There were no absent values for the five variables, and the total sample was 191. The dependent variable, ROA, has an average value of 4.82 , the average growth rate of total assets equals 0.9358 , and the average of Tobin's $Q$ is 1.51 . The averages of the control variables are 72.65 for the debt ratio and 12.98 for firm size.

The KEJI indexes are only evaluated for firms listed on the Korea Exchange, excluding firms with deficits, impaired capital, and compensation ratios below 1.0. It can therefore be inferred that the samples selected are of relatively large and financially sound firms.

\subsection{Correlation Analysis}

We report Pearson (bivariate) correlations between the main variables in Table 4. CSR is composed of six factors: soundness, fairness, social contribution, consumer protection, environmental protection satisfaction, and employee satisfaction. Financial performance is composed of ROA, the growth rate of total assets, and the index for corporate value, which is Tobin's $Q$. 
Table 4. Analysis results of the correlations between pairs of variables.

\begin{tabular}{|c|c|c|c|c|c|c|c|c|c|}
\hline Category & KEJI SO & KEJI FAIR & KEJI CSS & KEJI CPS & KEJI EP & KEJI ES & ROA & GROWTH & $\mathrm{TQ}$ \\
\hline KEJI SO & 1 & & & & & & & & \\
\hline $\begin{array}{l}\text { KEJI } \\
\text { FAIR }\end{array}$ & $\begin{array}{c}0.186^{* *} \\
0.010\end{array}$ & 1 & & & & & & & \\
\hline KEJI CSS & $\begin{array}{c}-0.040 \\
0.584\end{array}$ & $\begin{array}{c}-0.165 \text { ** } \\
0.022\end{array}$ & 1 & & & & & & \\
\hline KEJI CPS & $\begin{array}{c}-0.246^{* * *} \\
0.001\end{array}$ & $\begin{array}{c}0.176^{* *} \\
0.015\end{array}$ & $\begin{array}{c}-0.266^{* * *} \\
0.000\end{array}$ & 1 & & & & & \\
\hline KEJI EP & $\begin{array}{l}0.136 \\
0.061\end{array}$ & $\begin{array}{c}-0.355^{* * *} \\
0.000\end{array}$ & $\begin{array}{l}0.033 \\
0.651\end{array}$ & $\begin{array}{c}-0.066 \\
0.364\end{array}$ & 1 & & & & \\
\hline KEJI ES & $\begin{array}{c}-0.090 \\
0.216\end{array}$ & $\begin{array}{l}0.018 \\
0.810\end{array}$ & $\begin{array}{c}-0.115 \\
0.113\end{array}$ & $\begin{array}{l}0.054 \\
0.459\end{array}$ & $\begin{array}{c}-0.273 * * * \\
0.000\end{array}$ & 1 & & & \\
\hline ROA & $\begin{array}{c}0.149^{* *} \\
0.039\end{array}$ & $\begin{array}{c}-0.152 * * \\
0.036\end{array}$ & $\begin{array}{c}0.176^{* *} \\
0.015\end{array}$ & $\begin{array}{c}-0.112 \\
0.124\end{array}$ & $\begin{array}{l}0.052 \\
0.472\end{array}$ & $\begin{array}{c}-0.016 \\
0.822\end{array}$ & 1 & & \\
\hline GROWTH & $\begin{array}{l}0.041 \\
0.570\end{array}$ & $\begin{array}{l}0.030 \\
0.675\end{array}$ & $\begin{array}{c}-0.154 * * \\
0.034\end{array}$ & $\begin{array}{l}-0.154^{* *} \\
0.034\end{array}$ & $\begin{array}{c}-0.077 \\
0.288\end{array}$ & $\begin{array}{c}-0.013 \\
0.861\end{array}$ & $\begin{array}{l}0.044 \\
0.545\end{array}$ & 1 & \\
\hline $\mathrm{TQ}$ & $\begin{array}{c}0.203 * * * \\
0.005\end{array}$ & $\begin{array}{c}-0.140 \\
0.054\end{array}$ & $\begin{array}{c}-0.184 \\
0.011\end{array}$ & $\begin{array}{c}-0.184^{* *} \\
0.011\end{array}$ & $\begin{array}{l}0.097 \\
0.180\end{array}$ & $\begin{array}{c}-0.056 \\
0.440\end{array}$ & $\begin{array}{c}0.315^{* * * *} \\
0.000\end{array}$ & $\begin{array}{c}0.187^{* * * *} \\
0.010\end{array}$ & 1 \\
\hline
\end{tabular}

Pearson correlations are computed between the dependent and independent variables, shown in Table 4.

The relationship between ROA performance and CSR performance measured by the KEJI index has a positive correlation with the evaluation items of soundness and social contribution at a significance level below $5 \%$. However, the correlation coefficient between $R O A$ and fairness is -0.152 and below the $5 \%$ significance level, indicating a negative correlation. As for protection of environment, the result is not statistically significant, but has a positive correlation with ROA. Examining the correlation between CSR performance and the growth rate of total assets, only social contribution has a positive correlation under the significance level of $1 \%$.

However, satisfaction of consumer protection has a negative correlation under the $5 \%$ significance level. In the case of soundness, fairness, environmental protection satisfaction, and employee satisfaction, there is no statistically significant correlation with the growth rate of total assets. In the relationship between CSR performance and Tobin's $Q$, only the evaluation item soundness has a positive correlation at the $1 \%$ significance level. However, consumer protection shows a negative correlation at the $5 \%$ significance level. In the case of fairness, social contribution, environmental protection satisfaction, and employee satisfaction, the correlations with Tobin's $Q$ are not statistically significant.

\subsection{Testing of Research Hypotheses}

In general, the problem of multicollinearity might arise when multiple independent variables exist and factors that exert statistically significant influence might not be significant, or the signs of the results might even be opposite. Thus, when interpreting the results of multiple regression analysis, the presence of multicollinearity must be tested for. Our tests for multicollinearity indicate that this multiple regression analysis has no multicollinearity problem. In particular, we employ the following model to examine the relationships between lagged CSR-related variables and firm performance/value:

$$
\begin{gathered}
\text { ROA } / \text { GROWTH } / \text { TQ }_{i, t}=\alpha+\beta_{1} \cdot \text { CSR-related variables }_{i, t-1}+\beta_{2} \cdot \text { SIZE }_{i, t-1}+\beta_{3} \cdot \text { LEV }_{i, t-1}+ \\
\beta_{4} \cdot \text { R\&D }_{i, t-1}+\beta_{5} \cdot \mathrm{CF}_{i, t-1}+\beta_{6} \cdot \text { VOL }_{i, t-1}+\varepsilon_{i, t} \cdot
\end{gathered}
$$

We estimate panel regression models based on Petersen's approach in order to reflect time-series and cross-sectional correlations and thus compute the $t$-statistics using two-way clustered standard errors. Table 5 presents the estimation results. The results of the regression analysis with the CSR variable as the independent variable, and profitability, growth potential, and corporate value as dependent variables are as follows: 
Table 5. Effects of CSR on ROA/GROWTH/TQ.

\begin{tabular}{|c|c|c|c|c|c|c|}
\hline \multirow[b]{2}{*}{ Intercept } & \multicolumn{2}{|c|}{ Model 1: ROA } & \multicolumn{2}{|c|}{ Model 2: GROWTH } & \multicolumn{2}{|c|}{ Model 3: TOBIN's Q } \\
\hline & $\begin{array}{c}4.490 * * * \\
(11.12)\end{array}$ & $\begin{array}{c}3.803 * * * \\
(11.17)\end{array}$ & $\begin{array}{c}3.176^{* * *} \\
(12.23)\end{array}$ & $\begin{array}{c}2.191 * * * \\
(3.73)\end{array}$ & $\begin{array}{c}4.426^{* * *} \\
(55.33)\end{array}$ & $\begin{array}{c}3.801 * * * \\
(51.65)\end{array}$ \\
\hline Soundness $_{t-1}$ & $\begin{array}{c}0.015 \text { ** } \\
(2.45)\end{array}$ & & $\begin{array}{l}0.020 * \\
(1.96)\end{array}$ & & $\begin{array}{c}0.233^{* *} \\
(2.15)\end{array}$ & \\
\hline Fairness $_{t-1}$ & $\begin{array}{c}-0.283^{* *} \\
(-2.34)\end{array}$ & & $\begin{array}{l}0.168 \\
(0.65)\end{array}$ & & $\begin{array}{l}0.011 \\
(1.53)\end{array}$ & \\
\hline Social Contribution $_{t-1}$ & $\begin{array}{c}0.579 * * * \\
(3.81)\end{array}$ & & $\begin{array}{c}0.991^{* * *} \\
(3.39)\end{array}$ & & $\begin{array}{c}0.892 * * \\
(2.12)\end{array}$ & \\
\hline Consumer Protection $_{t-1}$ & $\begin{array}{l}-0.582 \\
(-0.47)\end{array}$ & & $\begin{array}{l}1.805 \\
(0.71)\end{array}$ & & $\begin{array}{l}-1.929 \\
(-1.76)\end{array}$ & \\
\hline Environment Protection $_{t-1}$ & $\begin{array}{l}0.323 \\
(1.21) \\
\end{array}$ & & $\begin{array}{l}0.323 \\
(0.39) \\
\end{array}$ & & $\begin{array}{l}0.170 \\
(1.21) \\
\end{array}$ & \\
\hline Employee Satisfaction $_{t-1}$ & $\begin{array}{l}0.752 \\
(0.92)\end{array}$ & & $\begin{array}{l}0.754 \\
(1.32)\end{array}$ & & $\begin{array}{l}0.431 \\
(1.13)\end{array}$ & \\
\hline Total $C S R_{t-1}$ & & $\begin{array}{c}0.854^{* * *} \\
(5.32)\end{array}$ & & $\begin{array}{c}0.446^{* * *} \\
(3.49)\end{array}$ & & $\begin{array}{c}0.384^{* * *} \\
(4.72)\end{array}$ \\
\hline$S I Z E_{t-1}$ & $\begin{array}{c}-0.316^{* * *} \\
(-3.81)\end{array}$ & $\begin{array}{c}-0.271^{* * *} \\
(-3.28)\end{array}$ & $\begin{array}{c}-0.2304 \text { * } \\
(-1.87)\end{array}$ & $\begin{array}{l}-0.163 \\
(-1.32)\end{array}$ & $\begin{array}{l}-0.100 \\
(-1.02)\end{array}$ & $\begin{array}{l}-0.070 \\
(-0.73)\end{array}$ \\
\hline$L E V_{t-1}$ & $\begin{array}{l}0.699 \\
(0.68)\end{array}$ & $\begin{array}{l}0.620 \\
(0.61)\end{array}$ & $\begin{array}{l}0.267 \\
(0.17)\end{array}$ & $\begin{array}{l}-0.022 \\
(-0.01)\end{array}$ & $\begin{array}{l}0.739 \\
(0.64)\end{array}$ & $\begin{array}{l}1.011 \\
(0.89)\end{array}$ \\
\hline$R \mathcal{E} D_{t-1}$ & $\begin{array}{c}-2.308^{* * *} \\
(-4.95)\end{array}$ & $\begin{array}{c}-1.783^{* * *} \\
(-3.77)\end{array}$ & $\begin{array}{c}-2.465^{* * *} \\
(-3.4)\end{array}$ & $\begin{array}{c}-1.324 \text { * } \\
(-1.7)\end{array}$ & $\begin{array}{l}0.732 \\
(1.34)\end{array}$ & $\begin{array}{l}0.925 * \\
(1.72)\end{array}$ \\
\hline$C F_{t-1}$ & $\begin{array}{l}0.360 \\
(0.59)\end{array}$ & $\begin{array}{l}0.481 \\
(0.79)\end{array}$ & $\begin{array}{l}0.984 \\
(1.01)\end{array}$ & $\begin{array}{l}1.011 \\
(1.05)\end{array}$ & $\begin{array}{l}-0.617 \\
(-0.97)\end{array}$ & $\begin{array}{l}-0.447 \\
(-0.72)\end{array}$ \\
\hline$V O L_{t-1}$ & $\begin{array}{c}0.772^{* * *} \\
(5.07)\end{array}$ & $\begin{array}{c}0.705 * * * \\
(4.65)\end{array}$ & $\begin{array}{c}1.222^{* * *} \\
(4.98)\end{array}$ & $\begin{array}{c}1.210 * * * \\
(4.97)\end{array}$ & $\begin{array}{c}0.851 * * * \\
(5.14)\end{array}$ & $\begin{array}{c}0.786^{* * *} \\
(4.84)\end{array}$ \\
\hline Adj. R-Square & 0.1657 & 0.1808 & 0.2293 & 0.2433 & 0.1004 & 0.1389 \\
\hline
\end{tabular}

First, the regression analysis was carried out using three separate versions: regression models 1,2 , and 3. The natural logarithm of the KEJI index has been used as the proxy variable for CSR performance, the independent variable. This study uses ROA as the proxy variable for profitability, GROWTH as the proxy variable for growth potential, and Tobin's $Q$ as the proxy variable for corporate value as dependent variables.

The correlation between CSR performance and profitability ROA (one of the proxy variables for corporate financial performance) is tested using the regression analysis of Hypothesis 4 .

Hypothesis 4. CSR will exert a significant influence on corporate profitability.

The results of examining the effects of CSR on ROA are as follows: The explanatory power of CSR for ROA is $16.57 \%$ (adjusted $R$ squared). Social contribution $(\beta=0.579, t=3.81$ ) has a positive correlation that is statistically significant at a significance level below $1 \%$. Soundness has a positive correlation that is statistically significant at a significance level below $5 \%$. Conversely, fairness $(\beta=-0.283, t=-2.34)$ has a significantly negative effect on profitability (ROA). Consumer protection is statistically insignificant even at the $10 \%$ significance level and has a negative correlation with profitability (ROA). To address the collinearity problems among the different measures from KEJI in the first column, we also consider 
the total CSR index in the regression estimation and the results are reported in the second column of Model 1. They show that the total CSR index positively influences ROA, consistent with the role of CSR engagement.

The relationship between CSR performance and GROWTH (among the indicators of financial performance) is tested through the regression analysis of Hypothesis 5 and the results are shown in Table 5.

Hypothesis 5. CSR will exert a statistically significant effect on firm growth.

Similarly, examining the effects CSR has on the growth rate of assets in Model 2, the explanatory power of CSR on GROWTH is $22.93 \%$ (adjusted $R$ squared). Soundness ( $\beta=0.020, t=1.96$ ) and social contribution ( $\beta=0.991, t=3.39$ ) are found to have statistically significant positive correlations with the growth rate of assets. However, fairness, consumer protection, environmental protection satisfaction, and employee satisfaction do not exert significant effects. We also find that the total CSR index positively influences GROWTH, implying that our findings are immune from the multicollinearity issue among diverse CSR matrices.

Finally, the relationship between CSR performance and corporate value (Tobin's $Q$ among the indicators of financial performance) is tested through the regression analysis of Hypothesis 6 we report our finds on the last two columns in Table 5.

Hypothesis 6. CSR will exert a statistically significant effect on corporate value.

Examining the effects CSR has on Tobin's $Q$, the explanatory power of CSR on Tobin's Q is $10.04 \%$ (adjusted $R$ squared). Soundness $(\beta=0.233, t=2.15)$ and social contribution $(\beta=0.892, t=1.12)$ have significantly positive correlation with Tobin's $Q$. On the contrary, consumer protection $(\beta=-1.929$, $t=-1.76$ ) is found to exert a statistically significant negative influence on corporate value. Moreover, fairness, environmental protection, and employee satisfaction are found not to exert significant effects. Consistent with previous studies, we find that the total CSR index positively affects Tobin's Q as shown in the last column of Table 5.

A summary of the results of the hypothesis testing is found in Table 6.

Table 6. Summary of the result of hypothesis testing.

\begin{tabular}{ccc}
\hline Hypothesis & Contents of Hypothesis & Results of Testing \\
\hline H1 & CSR will exert a significant influence on corporate profitability. & Partial Adoption \\
H2 & CSR will exert a statistically significant effect on the firm's growth. & Partial Adoption \\
H3 & CSR will exert a statistically significant effect on corporate value. & Partial Adoption \\
\hline
\end{tabular}

\section{Robustness Test}

Many global studies mention that the effect of CSR on corporate performance varies depending on industrial characteristics. This indicates that the approach to CSR should be different in each category of industry. For example, CSR would have a greater effect on the service and consumption industries because of public perception, which might be constructed by companies' social activities. By contrast, industrial and manufacturing businesses would not be significantly affected by public perception. Therefore, we will examine the differences in impact of CSR activities on corporate performance by industrial category. The corporate performance of firms dealing with consumption goods is sensitive to customer responses, whereas corporates dealing with industrial products, such as raw materials and supply items, might not respond as sensitively to customer reactions. Therefore, as a robustness check, we compare the effect of CSR on companies dealing in consumption goods and those dealing in industrial products as the last part of the empirical research. 
Table 7 shows the comparison between Service/Non-manufacturing and Manufacturing/etc. industries. We find that CSR activities have more impact on the Service/Non-manufacturing industry than on Manufacturing/etc. industries. This result corroborates that the consumption goods' industry responds sensitively to public reaction; whereas, in terms of industrial products, constructing public preferences is difficult, and thus CSR influence is lower than in other businesses.

Table 7. Effects of CSR on ROA/GROWTH/TQ by industry.

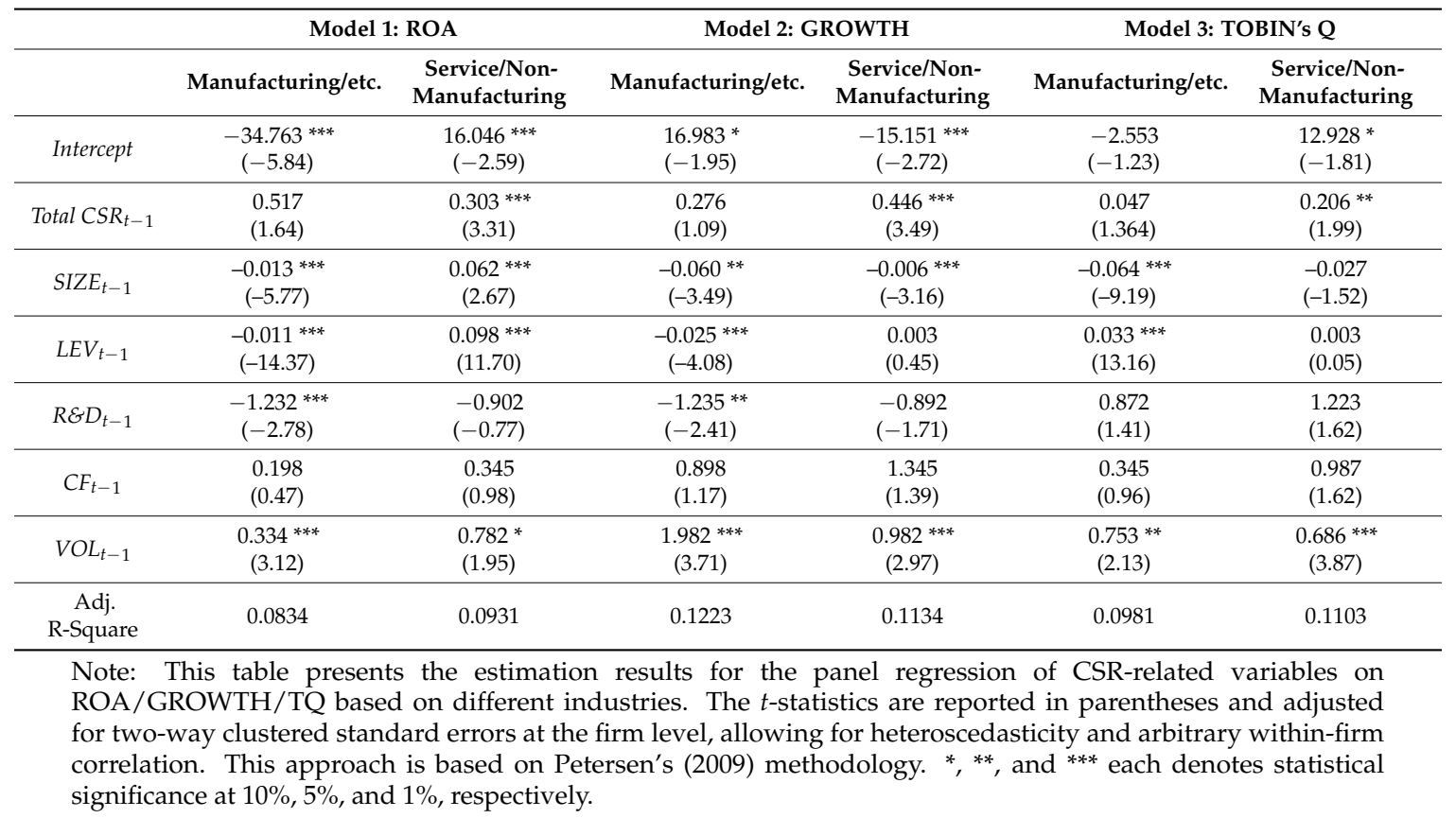

\section{Conclusions}

\subsection{Summary of Research Results}

The research on CSR activities is becoming an important assignment for academia and businesses worldwide. This study conducted an empirical analysis to examine whether there is a correlation between financial performance and CSR performance. The analysis is based on the stakeholder theory that CSR activities relieve various potential conflicts among different stakeholders, and that they enhance firm reputations. This will not only have positive effects on short-term financial performance, but also on long-term firm value.

The samples in this study use the KEJI index measured by the Korean Economic Justice Institute and 200 indexes surveyed in 2015 are used for analysis. Among the KEJI indexes calculated at the end of 2015, nine samples of companies with deficits, impaired capital, and times interest earned ratio below 1.0 are excluded from the 200 samples. Accordingly, a total of 191 firms are analyzed. We use the six evaluation items suggested by KEJI—soundness, fairness, contribution to social service, consumer protection satisfaction, environmental protection satisfaction, and employee satisfaction-as the variables of CSR (independent variable). ROA and the growth rate of assets are chosen as proxy variables for financial performance to measure profitability and growth, respectively. Corporate value is measured by Tobin's Q. Moreover, the control variables of debt ratio and firm size are used, with the natural log value of assets chosen to measure firm size. Financial data is obtained from TS2000 of Korea Companies Information.

In the correlation between CSR performance and profitability (ROA), only social contribution has a positive $(+)$ relationship at a significance level below $5 \%$. While soundness and environmental protection have a positive relationship with ROA, they are not statistically significant at a significance level of $10 \%$ or below. Examining the correlation between CSR performance and the growth rate 
(GROWTH), only the items of soundness and social contribution have a statistically significant positive correlation. In terms of corporate value measured with Tobin's $Q$, soundness and social contribution have a statistically significant positive correlation at a significance level below $5 \%$. While environmental protection has a positive directionality with corporate value (Tobin's Q), the result is not statistically significant even at the $10 \%$ level. On the contrary, consumer protection exerts a statistically significant negative influence on corporate value. The size of the firm has a positive effect on financial performance, and the debt ratio has a negative effect.

The hypotheses that CSR performance will exert positive effects on financial performance are partially supported. These results indicate that while CSR activities exert a positive influence on financial performance, not all CSR activities exert statistically significant effects on financial performance. Accordingly, firms should concentrate on those CSR activities that display significant results, ensuring that they only engage in efficient, effective activities.

\subsection{Implications, Distinctions, and Limitations of This Study}

\subsubsection{Study Implications Concerning CSR}

First, the results of this research indicate that CSR activities are not merely expenditure but are also investment and management strategies that can enhance corporate performance and value. To examine the results found in previous literature, this study uses the amended KEJI index (post 2015) which has excluded the evaluation item contribution to economic development to enhance its characteristic as an evaluation indicator of CSR. Our results partially support a positive correlation between CSR and financial performance.

Second, this study suggests the importance of social service contributions as the most relevant factor for enhancing short-term financial performance. Among the CSR evaluation items, social service contribution received the lowest evaluation as of the 2015 samples. However, it is the only evaluation item that has a positive correlation with all the financial performance indicators- $\mathrm{ROA}$, GROWTH, and Tobin's Q. These findings suggest that companies need more support and investment in community services such as protection of the marginalized, employment, donations, and social welfare support.

\subsubsection{The Differentiation Factor of This Study from Previous Literature}

Most previous studies have analyzed firm financial performance through single indicators, like ROA and Tobin's $Q$, to measure financial performance and its relationship with CSR performance. Thus, there has been insufficient analysis of the relationship between growth performance (another important indicator of financial performance other than those related to return on total assets or capital like ROA or ROE) and CSR performance. Accordingly, this study uses ROA, Tobin's Q, and the growth rate of assets as proxy variables for financial performance to examine the correlation with CSR performance. Through this, the indicators for financial performance have been expanded, and while the results are not unanimous, the study has been able to partially verify that CSR performance has a positive correlation with firm profitability, growth, and corporate value.

\subsubsection{Research Limitations and Future Research}

We discuss the limitations of this research and propose recommendations for future research as described below. First, the samples used in this study are limited to relatively large corporations and companies with good financial performance among Korean companies. The KEJI index, the object of the sample selection, is obtained only for firms listed in the Korean stock market, and those with deficits and poor financial structure are excluded. Therefore, small- and medium-sized enterprises (SMEs) that are not listed on the stock exchange or companies with relatively poor financial structures could not be included in the study. Future research should broaden the sample to these companies, so that the analysis of the correlation between CSR and financial performance can be generalized. 
Second, there is a time lag in the KEJI index. There is a time difference of about two years between the time of evaluation and the time of presentation of the KEJI Index. Accordingly, it is difficult to predict the CSR performance of those firms that are currently engaged in CSR activities. Accordingly, if the time difference is shortened to 1 year, the prediction of performance is expected to be much faster. If these limitations are minimized, it will be possible to predict CSR and corporate performance in real time, and more sophisticated research will be possible. Third, this study fails to analyze the relevance of various indicators, profits, and costs of financial performance to CSR activities. We added the variable growth rate of assets to complement ROA and Tobin's $Q$, the variables most commonly used for analysis in previous literature. However, this study does not include a detailed analysis of how profits, costs, and other indicators of financial performance (activity, productivity, PE, EVA, capital cost, etc.) are related to CSR performance. Future research will need to analyze how the various financial performance indicators and revenue and cost items are related to CSR. Fourth, this study indicates that consumer protection and environmental protection do not have a positive correlation with financial performance, at least in the short term. Thus, the increase in profitability or corporate value after investing in consumer and environmental protection seems to be less than the total expenditure. However, if the duration of the term under analysis is widened, the results of investments in consumer protection and environmental protection will be different. Considering the recent increase in the importance of consumer and environmental protection, more studies are necessary to gain insight into what effects these CSR activities exert on a firm's financial performance-profitability in the midto long-term.

This study is also subject to several caveats concerning the empirical set-up. First, our estimator might be biased because of a potential endogeneity problem. Possible treatments to endogeneity involve performing additional robustness tests using instrumental variables, lagged independent/dependent variables, or setting up a dynamic model, all of which are outlined in [121-123]. Second, using a different proxy for firm size other than the current one (natural log of total assets) might improve test results and ensure robustness $[124,125]$. Third, introducing a channel, for example corporate governance mechanisms [126,127], through which corporate investment in CSR affect corporate financial performance might yield more comprehensive results. Lastly, designing a better model specification that incorporates more variables to tease out possible confounding factors, and/or a moderator for better understanding of the relation, and/or market specific variables such as an indicator dummy for chaebols to discern market specific effects on the relation, could provide more market-based discernable test results. We leave these aspects to future research.

Author Contributions: C.Y.C. designed the research. S.J.C. performed research and analyzed the data. C.Y.C., S.J.C. and J.Y. wrote the paper. All authors read and approved the final manuscript.

Funding: This research received no external funding.

Acknowledgments: We would like to thank the four reviewers for their helpful comments and suggestions.

Conflicts of Interest: The authors declare no conflict of interest.

\section{References}

1. Shin, Y.G. Socially Responsible Management; Kyungmoonsa: Seoul, Korea, 2001; p. 554.

2. Aupperle, K.; Carroll, A.; Hatfield, J. An empirical examination of the relationship between corporate social responsibility and profitability. Acad. Manag. J. 1985, 28, 446-463.

3. Jamali, D.; Mirshak, R. Corporate social responsibility: Theory and practice in a developing country context. J. Bus. Ethics 2007, 72, 243-262. [CrossRef]

4. Park, Y.K. Evaluating the performance of trading strategies based on corporate social responsibility. Korea J. Bus. Adm. 2013, 26, 891-907.

5. Jung, Y.S. Prepare for corporate social responsibility (CSR). LG Wkly. Econ. 2005, 858, 3-7.

6. Federation of Korean Industries. 2006 White Paper on the Society Contribution of Major Firms and Company Foundations; FKI Media Co., Ltd.: Seoul, Korea, 2006. 
7. Yang, J.S.; Yeo, Y.J.; Kwon, O.J. The effect of excellence in corporate social responsibility activities on accounting conservatism. Korea Manag. Assoc. Manag. Stud. 2013, 43, 1937-1961.

8. Carroll, A. A three-dimensional conceptual model of corporate performance. Acad. Manag. Rev. 1979, 4, 497-505. [CrossRef]

9. Korea Nonprofit Research Academy. Development Research Report of Corporate Social Contribution Indicators; FKI Media Co., Ltd.: Seoul, Korea, 2005.

10. Bowen, H.R. Social Responsibility of the Businessman; No. 3; Harper: New York, NY, USA, 1953.

11. Heo, M.O.; Chung, K.H. A study on relationship between CSR performance and corporate value: Focus on mediation effect of corporate reputation. J. Ind. Econ. Bus. 2010, 23, 749-771.

12. Jang, J.I.; Choi, H.S. The relation between corporate social responsibility and financial performance. Daehan J. Bus. 2010, 23, 633-648.

13. Davis, K.; Blomstorm, R. Business and Society: Environment and Responsibility, 3rd ed.; Mcgraw Hill Book Company: New York, NY, USA, 1975.

14. ISO (2010). Social Responsibility: 7 Core. Available online: www.iso.org (accessed on 15 January 2018).

15. Roh, H.K. Examining Social Responsibility through ISO 26000; Parkyoungsa: Seoul, Korea, 2011; p. 342.

16. Carroll, A.B. Corporate social responsibility evolution of a definitional construct. Bus. Soc. 1991, 38, $268-295$.

17. Maignan, I.; Ferrell, O.C.; Ferrell, L. A stakeholder model for implementing social responsibility in marketing. Eur. J. Mark. 2005, 39, 956-977. [CrossRef]

18. Maignan, I.; Ferrell, O.C. Antecedents and benefits of corporate citizenship: An investigation of French business. J. Bus. Res. 2001, 51, 37-51. [CrossRef]

19. Luo, X.; Bhattacharya, C.B. Corporate social responsibility, customer satisfaction, and market value. J. Mark. 2006, 70, 1-18. [CrossRef]

20. McWilliams, A.; Siegel, D. Corporate social responsibility and financial performance: Correlation or misspecification? Strat. Manag. J. 2000, 21, 603-609. [CrossRef]

21. Park, Y.J. The Effects of Social Contribution on the Resolution of Crises in Rrganization. Master's Thesis, University of Chung-Ang, Seoul, Korea, 2007.

22. Kim, S.I. Study on the Effect of the Advertisement Messages of Corporate Social Responsibility on the Customer's Attitude Toward. Master's Thesis, University of Hongik, Seoul, Korea, 2008.

23. Chae, H.G. (A) Study on the Corporate Social Responsibility for Promotion of the Employment of the Disabled. Master's Thesis, University of Konkuk, Seoul, Korea, 2010.

24. Navarro, P. Why do corporations give to charity? J. Bus. 1988, 61, 65-93. [CrossRef]

25. Cho, H.O. The effects of corporate link advertisement on consumers decision making-A study on the role of the public properties and degree of brand familiarity. Advert. Res. 2000, 4, 14-29.

26. Lee, M.S.; Park, D.S.; Kim, J.B. Firms' characteristics and corporate social responsibilities. Bus. Res. 2009, 5, 70-81.

27. Friedman, M. The social responsibility of business is to increase its profits. New York Times Magazine, 13 September 1970; 32-33.

28. Kim, D.J. Effects of external activities of corporate social responsibility on benefits of employees and shareholders: Mainly from stakeholders' perspective. Korean Acad. Hum. Resour. Manag. 2009, 16, $29-47$. Available online: http:/ / www.kahrm.or.kr (accessed on 14 February 2018).

29. Drucker, P.F. Management: Task, Responsibilities, Practice; Harper Business: New York, NY, USA, 1973.

30. Freeman, R.E. Strategic Management: A Stakeholder Approach; Pitman: Boston, MA, USA, 1984.

31. Mitchell, R.K.; Agle, B.R.; Wood, D.J. Toward a theory of stakeholder identification and salience: Defining the principle of who and what really counts. Acad. Manag. Rev. 1997, 22, 853-886. [CrossRef]

32. Kim, Y.S. A Study on the Effects of Social Contribution Activities of Company Members on Corporate Performance and Sustainability. Ph.D. Thesis, University of Konkuk, Seoul, Korea, 2014.

33. Na, Y.; Hong, S.H. An empirical analysis on value relevance of corporate social responsibility activities by firm size. Korean Acc. Assoc. 2011, 20, 125-160.

34. Friedman, M. Capitalism and Freedom; University of Chicago Press: Chicago, IL, USA, 1970.

35. Davis, K. The case for and against business assumption of social responsibilities. Acad. Manag. J. 1973, 16, 312-322.

36. Barnea, A.; Rubin, A. Corporate social responsibility as a conflict between shareholders. J. Bus. Ethics 2010, 97, 71-86. [CrossRef] 
37. Shin, M.S.; Kim, S.E.; Kim, B.S. The effects of corporate social responsibility expenditure on firm value. J. Financ. Eng. 2011, 10, 99-125.

38. Kook, C.P.; Kang, Y.S. Corporate social responsibility, corporate governance, and firm value. Korean J. Financ. Stud. 2011, 40, 713-748.

39. Nelling, E.; Webb, E. Corporate social responsibility and financial performance: The virtuous circle revisited. Rev. Quant. Financ. Account. 2009, 32, 197-209. [CrossRef]

40. Bowman, E.H.; Haire, M. A strategic posture toward corporate social responsibility. Calif. Manag. Rev. 1975, 18,49-58. [CrossRef]

41. Hammond, S.A.; Slocum, J.W. The impact of prior firm financial performance on subsequent corporate reputation. J. Bus. Ethics 1996, 15, 159-165. [CrossRef]

42. Waddock, S.A.; Smith, N. Relationships: The real challenge of corporate global citizenship. Bus. Soc. Rev. 2000, 105, 47-62. [CrossRef]

43. Roh, J.H.; Choi, J.S. The relationship between CSR and financial constraints. Korea J. Bus. Adm. 2014, 27, 1329-1349.

44. Jones, T. Instrumental stakeholder theory: A synthesis of ethics and economics. Acad. Manag. Rev. 1995, 20, 404-437. [CrossRef]

45. Swanson, D.L. Toward an integrative theory of business and society: A research strategy for corporate social performance. Acad. Manag. Rev. 1999, 24, 506-521.

46. Han, J.H.; Nam, H.Y. The effects of corporate social responsibility on the cost of debt: Focused on firm characteristic. Korea J. Bus. Adm. 2013, 26, 2253-2274.

47. Ruf, B.M.; Muralidhar, K.; Brown, R.M.; Janney, J.J.; Paul, K. An empirical investigation of the relationship between change in corporate social performance and financial performance: A stakeholder theory perspective. J. Bus. Ethics 2001, 32, 143-156. [CrossRef]

48. Garcia-Castro, R.; Canela, M.A.; Arin, M.A. Over the long run? Short-run impact and long-run consequences of stakeholder management. Bus. Soc. 2011, 50, 428-455. [CrossRef]

49. Jung, Y.K.; Kim, S.H. Environmental issue and sustainability report. Korean Acc. Assoc. 2008, 3, 1-28.

50. Wei, P.R. An empirical analysis on the relations of corporate value and corporate social contribution. J. Bus. Res. 2006, 21, 97-125.

51. Choi, W.Y.; Lee, H.S.; Hong, C.S. Corporate social responsibility and firm value: Focused on corporate contributions. Korean Manag. Rev. 2009, 38, 407-432.

52. Kim, Y.S.; We, J.B. Comprehensive analysis of corporate social responsibility and financial performance. Korean J. Bus. Adm. 2011, 24, 2931-2950.

53. Kim, S.Y.; Jung, J.Y.; Xiu, F. Does corporate social responsibility lead to superior financial performance in the Internet era? U shaped relationship approach. Glob. E-Bus. Assoc. 2015, 16, 203-230.

54. Kim, M.L.; Kwon, I.S.; Sul, W.S. On the relationship among corporate governance, corporate social responsibility (CSR), and performance. J. CEO Manag. Stud. 2014, 17, 125-144.

55. Chon, M.L.; Kim, C.S. The effect of sustaining corporate social responsibility on relationship between CSR and financial performance. Korea Account. Inf. Res. Korea Account. Inf. Assoc. 2011, 29, 351-374.

56. Park, H.J.; Lee, J.G. Contribution and environmental protection: An empirical study on the relationship between social contribution activities and financial performance. Pers. Organ. Res. 2002, 10, 95-133.

57. Kang, J.H.; Kim, D.H. The study on the relations between corporate social responsibility and financial performance. J. Korea Acad.-Ind. Coop. Soc. 2010, 11, 681-688.

58. Kim, S.Y. Effects of Corporate Social Responsibility on the Finance Performance: Focused on Korea Economic Justice Index. Master's Thesis, University of Gachon, Seongnam, Korea, 2013.

59. Lee, D.Y. Corporate Social Responsibility and Firm Value. Master's Thesis, University of Hanyang, Seoul, Korea, 2011.

60. Yeo, Y.J.; Choi, S.J.; Kwon, O.J. CSR activities as a competitive strategy based on industry competition and firm performance: Focusing on the market type. Korean Account. Rev. 2015, 40, 1-37.

61. Chung, K.H.; Pruitt, S.W. A simple approximation of Tobin Q. Financ. Manag. 1994, 23, 70-74. [CrossRef]

62. Lim, H.C. Economic Justice Company Award, Past 20 Years and Future 20 Years. Economic Justice Company Award Presentation Data. KEJI Award Present. Data 2013, 15-26. Available online: http:/ /www.ccej.or.kr/ index.php?mid=page_org_1 (accessed on 3 January 2018).

63. Yoo, S.H. Cooperate Finance; Hyungseul Publishing: Seoul, Korea, 2003; pp. 407-429. 
64. Kim, S.H.; Lee, K.W. Corporate social responsibility (CSR) in accounting: Review and future direction. DAEHAN J. Bus. 2013, 26, 2397-2425.

65. Hillman, A.; Keim, G. Shareholder value, stakeholder management, and social issues: What's the bottom line? Strat. Manag. J. 2001, 22, 125-139. [CrossRef]

66. Lee, W.J.; Chung, S.W.; Bae, S.H. Relation between corporate social responsibility and accounting information. Korean Acc. Assoc. 2012, 2, 1-21.

67. Lee, J.W. Labor related global movement and implication for corporate social responsibility. Labor. Rev. 2007, 5, 35-48.

68. Cheung, Y.L.; Tan, W.; Ahn, H.J.; Zhang, Z. Does corporate social responsibility matter in Asian emerging markets? J. Bus. Ethics 2010, 92, 401-413. [CrossRef]

69. Nam, Y.S.; Jun, H. The shaping of corporate social responsibility in Korea's economic development. Glob. J. Bus. Manag. Acc. 2011, 1, 10-20.

70. Sharma, B. Contextualising CSR in Asia: Corporate Social Responsibility in Asian Economies; Singapore Management University: Singapore, 2013.

71. Cho, E.; Chun, S.; Choi, D. International diversification, corporate social responsibility, and corporate governance: Evidence from Korea. J. Appl. Bus. Res. 2015, 31, 743-764. [CrossRef]

72. Choi, S.; Aguilera, R.V. CSR dynamics in South Korea and Japan: A comparative analysis. In Corporate Social Responsibility: A Case Study Approach; Mallin, C., Ed.; Edward Elgar Publishing Ltd.: New York, NY, USA, 2009; pp. 123-147.

73. Choi, B.B.; Lee, D.; Park, Y. Corporate social responsibility, corporate governance and earnings quality: Evidence from Korea. Corp. Gov. Int. Rev. 2013, 21, 447-467. [CrossRef]

74. Brown, T.J.; Dacin, P.A. The company and the product: Corporate associations and consumer product responses. J. Mark. 1997, 61, 68-84. [CrossRef]

75. Mackey, A.; Mackey, T.B.; Barney, J.B. Corporate social responsibility and firm performance: Investor preferences and corporate strategies. Acad. Manag. Rev. 2007, 32, 817-835. [CrossRef]

76. Friedman, M. A theoretical framework for monetary analysis. J. Polit. Econ. 1970, 78, 193-238. [CrossRef]

77. McWilliams, A.; Siegel, D. Corporate social responsibility: A theory of the firm perspective. Acad. Manag. Rev. 2001, 26, 117-127. [CrossRef]

78. Brown, W.O.; Helland, E.; Smith, J.K. Corporate philanthropic practices. J. Corp. Financ. 2006, $12,855-877$. [CrossRef]

79. Harjoto, M.A.; Jo, H. Why do Firms Engage in Corporate Social Responsibility? Working Paper; Santa Clara University: Santa Clara, CA, USA, 2007.

80. McGuire, J.W. Business and Society; McGraw-Hill: New York, NY, USA, 1963.

81. Fredrik, W.C. From CSR1 to CSR2: The maturing of business-and-society thought. Bus. Soc. 1994, 33, 150-164. [CrossRef]

82. Vance, S.C. Are socially responsible corporations good investment risks? Manag. Rev. 1975, 64, 19-24.

83. Wright, P.; Ferris, S.P. Agency conflict and corporate strategy: The effect of divestment on corporate value. Strat. Manag. J. 1997, 18, 77-83. [CrossRef]

84. Bartlett, A.; Preston, D. Can ethical behaviour really exist in business? J. Bus. Ethics 2000, 23, $199-209$. [CrossRef]

85. Cochran, P.L.; Wood, R.A.; Jones, T.B. The composition of boards of directors and incidence of golden parachutes. Acad. Manag. J. 1985, 28, 664-671.

86. Freeman, C. Long Waves in the World Economy; F. Pinter: London, UK, 1984.

87. Waddock, S.A.; Graves, S.B. The corporate social performance-financial performance link. Strat. Manag. J. 1997, 18, 303-319. [CrossRef]

88. Posnikoff, J. Disinvestment from South Africa: They did well by doing good. Contemp. Econ. Policy 1997, 15, 76-86. [CrossRef]

89. Roman, R.M.; Hayibor, S.; Agle, B.R. The relationship between social and financial performance: Repeating a portrait. Bus. Soc. 1999, 38, 109-125. [CrossRef]

90. Margolis, J.D.; Walsh, J.P. Misery loves companies: Rethinking social initiatives by business. Adm. Sci. Q. 2003, 48, 268-305. [CrossRef]

91. Karmer, M.R. Measuring Innovation: Evaluation in the Field of Social Entrepreneurship; Foundation Strategy Group and Skoll Foundation: San Francisco, CA, USA, 2002. 
92. David, P.; Kline, S.; Dali, Y. Corporate social responsibility, practices, corporate identity and purchase intention: A dual process model. J. Public Relat. Res. 2006, 17, 291-313. [CrossRef]

93. Park, H.J.; Lee, J.G. Donation and environment protection: Relation between CSR and financial performance. Hum. Resour. Struct. Res. 2002, 10, 95-133.

94. Park, H.J.; Kwon, I.S.; Shin, H.H.; Chung, J.W. The relation between corporate environmental achievements and corporate achievements. Bus. Manag. Res. 2004, 33, 1461-1487.

95. Kim, C.S. Corporate social responsibility activities and corporate value. Korean Secur. Assoc. 2009, 38, 507-545.

96. Choi, U.Y.; Lee, H.S.; Hong, C.S. The impact of CSR on firm value: Focusing on the expenditure. Bus. Manag. Res. 2009, 38, 407-432.

97. Lee, J.M.; Kim, Y. The effects of corporate social responsibility on firm value. JACC 2013, 35, $27-55$.

98. El Ghoul, S.; Guedhami, O.; Kwok, C.C.; Mishra, D.R. Does corporate social responsibility affect the cost of capital? J. Bank. Financ. 2011, 35, 2388-2406. [CrossRef]

99. Wu, S.I.; Lin, H.F. The correlation of CSR and consumer behavior: A study of convenience store. Int. J. Mark. Stud. 2014, 6, 66-80. [CrossRef]

100. Janney, J.J.; Gove, S. Reputation and corporate social responsibility aberrations, trends, and hypocrisy: Reactions to firm choices in the stock option backdating scandal. J. Manag. Stud. 2011, 48, 1562-1585. [CrossRef]

101. Turban, D.B.; Greening, D.W. Corporate social performance and organizational attractiveness to prospective employees. Acad. Manag. J. 1997, 40, 658-672.

102. Kim, H.; Park, K.; Ryu, D. Corporate environmental responsibility: A legal origins perspective. J. Bus. Ethics 2017, 140, 381-402. [CrossRef]

103. Davidson, W.N.; Worrell, D.L.; Lee, C.I. Stock market reactions to announced corporate illegalities. J. Bus. Ethics 1994, 13, 979-987. [CrossRef]

104. Gunthorpe, D.L. Business ethics: A quantitative analysis of the impact of unethical behavior by publicly traded corporations. J. Bus. Ethics 1997, 16, 537-543. [CrossRef]

105. Westphal, J.D. Collaboration in the boardroom: Behavioral and performance consequences of CEO-board social ties. Acad. Manag. J. 1999, 42, 7-24.

106. Kaplan, S.N.; Zingales, L. Do investment-cash flow sensitivities provide useful measures of financing constraints? Q. J. Econ. 1997, 112, 169-215. [CrossRef]

107. Dang, C.; Li, Z.F.; Yang, C. Measuring firm size in empirical corporate finance. J. Bank. Financ. 2018, 86, 159-176. [CrossRef]

108. Chapple, W.; Moon, J. Corporate social responsibility (CSR) in Asia: A seven-country study of CSR web site reporting. Bus. Soc. 2005, 44, 415-441. [CrossRef]

109. Welford, R. Corporate social responsibility in Europe and Asia. J. Corp. Citizsh. 2004, 13, 33-52. [CrossRef]

110. Kim, C.H.; Amaeshi, K.; Harris, S.; Suh, C.J. CSR and the national institutional context: The case of South Korea. J. Bus. Res. 2013, 66, 2581-2591. [CrossRef]

111. Witt, M.A.; Redding, G. The spirits of corporate social responsibility: Senior executive perceptions of the role of the firm in society in Germany, Hong Kong, Japan, South Korea and the USA. Socioecon. Rev. 2011, 10, 109-134. [CrossRef]

112. Jones, R.; Murrell, A.J. Signaling positive corporate social performance: An event study of family-friendly firms. Bus. Soc. 2001, 40, 59-78. [CrossRef]

113. Loh, L.; Thomas, T.; Wang, Y. Sustainability reporting and firm value: Evidence from Singapore-listed companies. Sustainability 2017, 9, 2112. [CrossRef]

114. Singh, P.J.; Sethuraman, K.; Lam, J.Y. Impact of corporate social responsibility dimensions on firm value: Some evidence from Hong Kong and China. Sustainability 2017, 9, 1532. [CrossRef]

115. Hategan, C.-D.; Curea-Pitorac, R.-I. Testing the correlations between corporate giving, performance and company value. Sustainability 2017, 9, 1210. [CrossRef]

116. Kim, W.S.; Park, K.; Lee, S.H. Corporate social responsibility, ownership structure, and firm value: Evidence from Korea. Sustainability 2018, 10, 2497. [CrossRef]

117. Li, F. Endogeneity in CEO power: A survey and experiment. Invest. Anal. J. 2016, 45, 149-162. [CrossRef]

118. Orlitzky, M.; Benjamin, J.D. Corporate social performance and firm risk: A meta-analytic review. Bus. Soc. 2001, 40, 369-396. [CrossRef] 
119. Porter, M.E.; Kramer, M.R. The big idea: Creating shared value. Harv. Bus. Rev. 2011, 89, 62-77.

120. Lins, K.V.; Servaes, H.; Tamayo, A. Social capital, trust, and firm performance: The value of corporate social responsibility during the financial crisis. J. Financ. 2017, 72, 1785-1824. [CrossRef]

121. Buchanan, B.; Cao, C.X.; Chen, C. Corporate social responsibility, firm value, and influential institutional ownership. J. Corp. Financ. Forthcom. 2018, 52, 73-95. [CrossRef]

122. Hong, H.; Kubik, J.D.; Scheinkman, J.A. Financial Constraints on Corporate Goodness (No. w18476); National Bureau of Economic Research: Cambridge, MA, USA, 2012.

123. Surroca, J.; Tribo, J.A. Managerial entrenchment and corporate social performance. J. Bus. Financ. Account. 2008, 35, 748-789. [CrossRef]

124. Campbell, J.L. Why would corporations behave in socially responsible ways? An institutional theory of corporate social responsibility. Acad. Manag. Rev. 2007, 32, 946-967. [CrossRef]

125. Grewatsch, S.; Kleindienst, I. When does it pay to be good? Moderators and mediators in the corporate sustainability-corporate financial performance relationship: A critical review. J. Bus. Ethics 2017, 145, 383-416. [CrossRef]

126. Kapoor, S.; Sandhu, H.S. Does it pay to be socially responsible? An empirical examination of impact of corporate social responsibility on financial performance. Glob. Bus. Rev. 2010, 11, 185-208. [CrossRef]

127. Li, Z.F. Mutual monitoring and corporate governance. J. Bank. Financ. 2014, 45, 255-269.

(C) 2019 by the authors. Licensee MDPI, Basel, Switzerland. This article is an open access article distributed under the terms and conditions of the Creative Commons Attribution (CC BY) license (http://creativecommons.org/licenses/by/4.0/). 